\title{
Phenotypic association of seven observed traits of hand complex
}

\author{
Abdurahim Kalajdžić ${ }^{1}$, Naris Pojskić ${ }^{1}$, Tarik Corbo $^{1} \&$ Rifat Hadžiselimović ${ }^{1}$ \\ ${ }^{1}$ University of Sarajevo - Institute for Genetic Engineering and Biotechnology, Zmaja od Bosne 8, 71000 Sarajevo, Bosnia and Herzegovina \\ * Corresponding author: abdurahim.kalajdzic@ingeb.unsa.ba
}

Received October 11 $11^{\text {th }}, 2021$

Accepted for publication October $28^{\text {th }}, 2021$

Online First November $5^{\text {th }}, 2021$

Keywords: phenotype, association, hand-related traits.

\section{Abstract}

This paper provides an overview of the seven possible hand-related traits, with an idea to estimate the statistical phenotypic association between them. The traits observed in this study were: midphalangeal hair, Hitchhiker's thumb, extensibility of proximal joint of thumb, digital index, nail shape, crooked fifth finger and hand clasping. The mentioned characteristics were observed in 7431 unrelated subjects, with approximately equal gender distribution. For each case, three groups were formed: total, male and female. The subjects were evenly distributed throughout Bosnia and Herzegovina's various geographical regions, and they properly represent the country's national and ethnic composition. The Chi-squared test was used to determine the statistical significance of the association between these traits, while Fisher's exact test was utilized as an extra test to analyze the association between each pair of observed features. Also, Chi-squared test was applied for observing differences in the frequencies of the phenotypic characteristics of the hand between the genders. Following traits were shown to have a statistically significant association: midphalangeal hair-Hitchhiker's thumb, midphalangeal hair digital index, midphalangeal hair - nail shape, midphalangeal hair - crooked fifth finger, Hitchhiker's thumb- extensibility of proximal joint of thumb, digital index - nail shape, digital index -crooked fifth finger, midphalangeal hair - hand clasping, crooked fifth finger - hand clasping. Analysis of differences in the frequencies of the observed phenotypic traits of the hand according to the genders showed statistical significance for $D$, Dht, Ref and Lf.

\section{Introduction}

In bioanthropological research, the focus was on relatively easily measurable traits, which is why we generally divide them into: dynamic-morphological, static-morphological and biochemical-physical. In most cases, such traits have an oligogenic or polygenic character, and it is not easy to assess the association. Therefore, one of the ways of perceiving the complexity of these traits is the phenotypic association, ie. evaluation of the association of phenotype variants.

Bioanthropological research in Bosnia and Herzegovina began during the Austro-Hungarian Empire in the late 19th century, and the history of such research is presented in Lasic et al. 2016. A number of bioanthropological and genetic studies have been performed in Bosnia and Herzegovina to assess the heterogeneity of local populations as well as the general B\&H population (Berberovic 1969; Dogan et al. 2016; Hadziselimovic 1981; Kapur-Pojskic et al. 2014; Kovacevic et al. 2013, 2014; Lasic et al. 2013, 2016, 2020; Marjanovic et al. 2005, 2005a, 2006, 2008; Pojskic et al. 2013). However, most of these works are based on molecular genetic markers, and a smaller part on phenotypic markers.

The assessment of heterogeneity in temporal time was done by Pojskic in 2003, and when it comes to assessing heterogeneity based on the hand phenotype and other phenotypic traits numerous studies were performed by B\&H scientists in the last century (Berberovic 1969, 1978; Berberovic et al. 1976; Hadziselimovic 1977, 1981; Hadziselimovic and Terzic 1985; Kaunic and Grin 1963). However, none of these papers included the assessment of the association of different phenotypic 
traits. Therefore, this paper presents an overview of the possible seven hand-related traits. Having a large data set, the assumption is that we can estimate the statistical association of hand-related phenotypes.

By reviewing the literature concerning the seven traits regarding complex of hand (Dutta 1965; Glass and Kistler 1953; Lai and Walsh 1965; Munir et al. 2010; Nesic et al. 2010; Phelps 1952;), the mode of inheritance was determined. These papers indicate variations of the stated traits, which in principle means variations of the genetic basis. Most of these traits are controlled by a set of multiple genes [polygenic traits] (Bernstein 1949). From all the above, it can be concluded that the study of the relationship between the phenotypic traits of the hand is very interesting approach in bioanthropology.

\section{Materials and methods}

Possible phenotypic association among seven traits regarding complex of hand was observed. Those seven traits were: midphalangeal hair (D), Hitchhiker's thumb (Dht), extensibility of proximal joint of thumb (Pht), digital index (Lf), nail shape (Ln), crooked fifth finger
(Ref) and hand clasping ( $\mathrm{Hc}$ ) (Table 1). A total of 7431 unrelated subjects were observed at random for these seven traits regarding complex of hand. Observed subjects were evenly distributed through different geographical regions of Bosnia and Herzegovina and duly represent characteristic national and ethnic composition (Fig.1). Total sample contained approximately equal gender distribution. Out of 7431, for a total of 6985 individuals, gender distribution was observed.

Therefore, in the analysis of frequencies of phenotypic variants and their association, only those samples whose gender association was known were analyzed. For determining statistical significance of association between these traits, Chi-squared test was calculated. As additional test for assessing the association between each pair of observed traits Fisher's exact test was utilized. For calculating these values, MedCalc version 18.10.2 was used. Considered statistical significance level was 0.05 . In order to observe the difference in the frequencies of the phenotypic characteristics of the hand between the genders, the Chi-squared test was applied with the considered level of statistical significance $p<0.05$. In every case, three groups were

Table 1. List of seven observed traits regarding complex of hand

\begin{tabular}{|c|c|c|c|c|c|}
\hline Trait & Abbreviation & Recessive & Variant I & Variant II & Author \\
\hline Hand clasping & $\mathrm{Hc}$ & I & Right-1 & Left-2 & Lutz, F.E. (1908) \\
\hline $\begin{array}{l}\text { Midphalangeal hair } \\
\text { (mid-digital hair) }\end{array}$ & D & Hairless & No hair-0 & Hairy-1 & $\begin{array}{c}\text { Danforth, C.H. (1921); } \\
\text { Bernstein (1949) }\end{array}$ \\
\hline $\begin{array}{l}\text { Nail shape } \\
\text { (Short nails) }\end{array}$ & Ln & Long nails & Non-flat-0 & Flat-1 & Gillin (1959) \\
\hline Crooked fifth finger & Ref & „Normal" phalanx & $\begin{array}{l}\text { Abnormally } \\
\text { crooked-0 }\end{array}$ & Normal-1 & $\begin{array}{c}\text { Hefner, R.A. (1929); } \\
\text { Hersh, A.H., F. } \\
\text { DeMarinis, R.M. } \\
\text { Stecher (1953); Dutta } \\
\text { (1965) }\end{array}$ \\
\hline Digital index & Lf & $\begin{array}{l}\text { short (\$o) and long } \\
\left(\sigma^{\prime} \sigma^{7}\right) \text { index finger }\end{array}$ & $\begin{array}{l}\text { Male-short- } \\
1 \text {; Female- } \\
\text { short-0 }\end{array}$ & $\begin{array}{l}\text { Male-long- } \\
0 \text {; Female- } \\
\text { long-1 }\end{array}$ & $\begin{array}{l}\text { Ecker (1875); } \\
\text { Phelps (1952) }\end{array}$ \\
\hline $\begin{array}{l}\text { "Hitch-hiker's" } \\
\text { thumb } \\
\text { (Extensibility of } \\
\text { distal joint of } \\
\text { thumb) }\end{array}$ & Dht & $\begin{array}{c}\text { "Hitch-hiker's" } \\
\text { thumb } \\
\text { (Hyperextensibility) }\end{array}$ & $\begin{array}{l}\text { Hypoextensi } \\
\text { bility-0 }\end{array}$ & $\begin{array}{l}\text { Hyperexten } \\
\text { sibility-1 }\end{array}$ & $\begin{array}{c}\text { Glass, B., Kistler, J.C. } \\
\text { (1953) }\end{array}$ \\
\hline $\begin{array}{l}\text { Extensibility of } \\
\text { proximal joint of } \\
\text { thumb }\end{array}$ & Pht & Hyperextensibility & $\begin{array}{l}\text { Hypoextensi } \\
\text { bility-0 }\end{array}$ & $\begin{array}{l}\text { Hyperexten } \\
\text { sibility-1 }\end{array}$ & $\begin{array}{l}\text { Whitney (1942) } \\
\text { Gillin (1959) }\end{array}$ \\
\hline
\end{tabular}




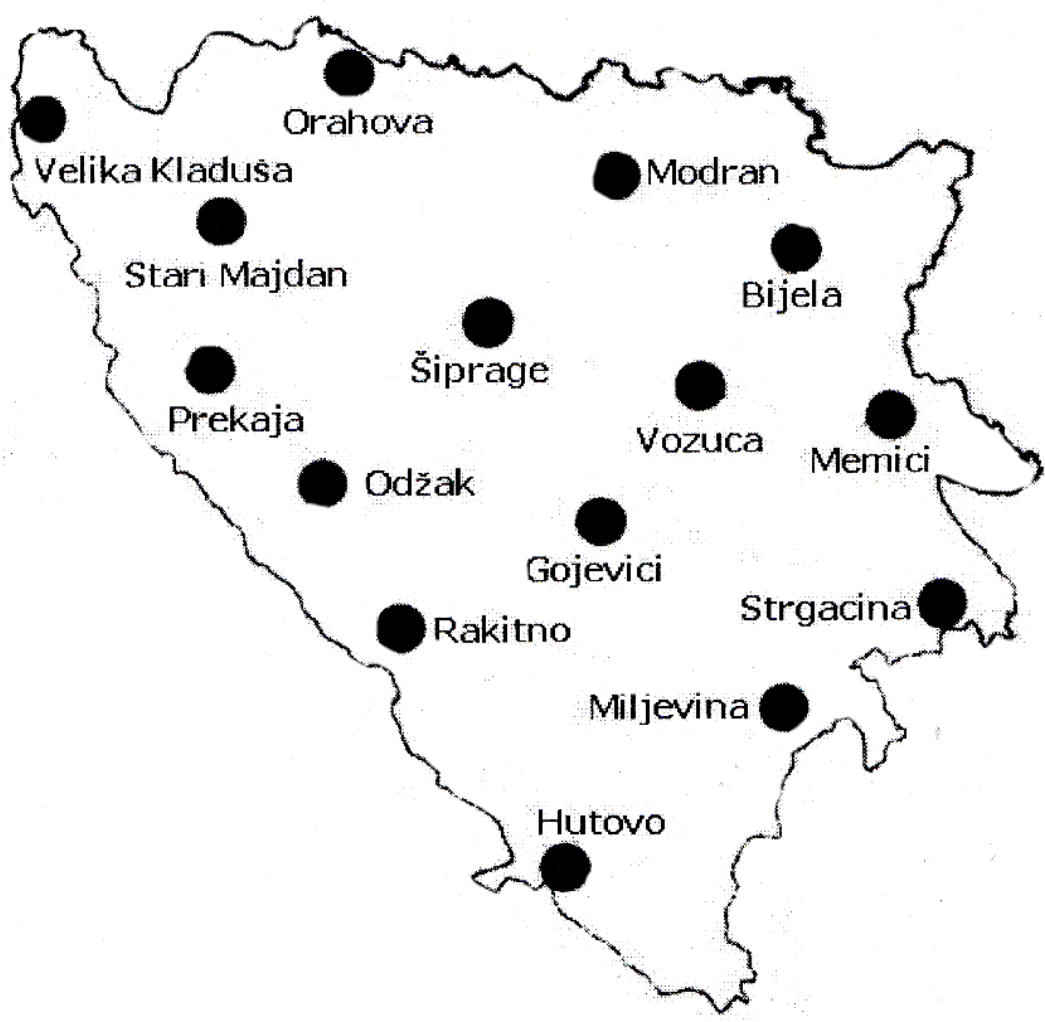

Figure 1 Distribution of observed local populations in Bosnia and Herzegovina

formed: total, male and female groups, in later paragraphs marked with $T$ (total), $F$ (female) and $M$ (male). Since there is a difference in the dominant inheritance of variants of the digital index trait between the genders, the assessment of the possible association of this trait with other observed traits was performed only for gender groups and not for the total population.

\section{Results and Discussion}

In table 1 a list of seven observed traits regarding complex of hand with its abbreviation is presented. The results of Fisher exact and Chi-squared test between seven observed traits for all three groups $(T, M, F)$ are presented in tables 2, 3, 4 .

The results of the analysis of differences in the frequencies of the observed phenotypic traits of the hand according to the genders showed statistical significance for $D(\chi 2=6.019, p=0.0142)$, Dht $(\chi 2=27.569$, $p<0.0001)$, Ref $(\chi 2=4.180, p=0.0409)$ and was not observed for Pht $(\chi 2=0.856, p=0.3548), \operatorname{Ln}(\chi 2=2.867$, $\mathrm{p}=0.0904)$ and $\mathrm{Hc}(\chi 2=0.187, \mathrm{p}=0.6655)$. A pronounced statistically significant difference was also observed for Lf $(x 2=715.546, p<0.0001)$, given that there is a different dominant phenotype depending on the gender. In our study, it was observed that the frequency of phenotype variants $D$, Dht and Ref, and expectedly Lf, also had a statistically significant difference between the genders. Thus, in trait $D$, the balance of phenotypes 0 and 1 in male group is observed, and in female group more pronounced 1 in relation to 0 . In the case of Dht, a larger difference was observed in different variants of this trait in female group than in male group, while in the case of Ref, slightly higher difference in phenotype variants is observed in male group rather than female group. As expected, there is a marked difference in Lf, since the dominant phenotype in female group is long index finger, and in male group short index finger.

Statistical significant association was observed between following traits: midphalangeal hair-Hitchhiker's thumb, midphalangeal hair - digital index, midphalangeal hair - nail shape, midphalangeal hair crooked fifth finger, Hitchhiker's thumb- extensibility of proximal joint of thumb, digital index - nail shape, digital index -crooked fifth finger, midphalangeal hair - hand clasping, crooked fifth finger - hand clasping (Fig.2A, 2B, 2C). 
Table 2. Fisher's exact test $p$-value and Chi squared value for total population in case of seven observed traits of hand complex (upper triangle - $\chi 2$ value; lower triangle - Fisher exact $p$ value; ${ }^{*} p<0.05 ; * * p<0.01 ; * * * p<0.001$ )

\begin{tabular}{|l|l|l|l|l|l|l|l|}
\hline & D & Dht & Lf & Ln & Ref & Pht & Hc \\
\hline D & & $7.976^{* *}$ & - & $31.343^{* * *}$ & $19.858^{* * *}$ & 0.016 & $4.692^{*}$ \\
\hline Dht & $0.0050^{* *}$ & & - & 3.613 & 0.000 & $58.979^{* * *}$ & 0.071 \\
\hline Lf & - & - & & - & - & - & - \\
\hline Ln & $0.0000^{* * *}$ & 0.0612 & - & & 0.006 & 1.997 & 1.445 \\
\hline Ref & $0.0000^{* * *}$ & 1.0000 & - & 0.9501 & & 1.676 & 3.599 \\
\hline Pht & 0.9238 & $<0.0000^{* * *}$ & - & 0.1610 & 0.2079 & & 0.002 \\
\hline Hc & $0.0321^{*}$ & 0.7920 & - & 0.2311 & 0.0610 & 0.9746 & \\
\hline
\end{tabular}

\$Since there is a difference in the dominant inheritance of variants of the digital index trait between the genders, the assessment of the possible association of this trait with other observed traits was performed only for gender groups and not for the total population (-)

Table 3. Fisher's exact test $p$-value and Chi squared value for male population in case of seven observed traits of hand complex (upper triangle - $\chi 2$ value; lower triangle - Fisher exact $p$ value; ${ }^{*} p<0.05 ; * * p<0.01 ; * * * p<0.001$ )

\begin{tabular}{|l|l|l|l|l|l|l|l|}
\hline & D & Dht & Lf & Ln & Ref & Pht & Hc \\
\hline D & & $5.596^{*}$ & $11.485^{* * *}$ & $10.208^{* *}$ & $11.994^{* * *}$ & 1.224 & 2.604 \\
\hline Dht & $0.0186^{*}$ & & 1.994 & 0.742 & 0.047 & $50.504^{* * *}$ & 0.477 \\
\hline Lf & $0.0007^{* * *}$ & 0.1678 & & $7.184^{* *}$ & $41.238^{* * *}$ & 0.011 & 0.138 \\
\hline Ln & $0.0015^{* *}$ & 0.4026 & $0.0081^{* *}$ & & 0.454 & 2.185 & 1.699 \\
\hline Ref & $0.0005^{* * *}$ & 0.8297 & $<0.0000^{* * *}$ & 0.5286 & & 1.596 & 0.991 \\
\hline Pht & 0.2699 & $<0.0000^{* * *}$ & 0.9165 & 0.1412 & 0.2256 & & 0.341 \\
\hline Hc & 0.1082 & 0.4926 & 0.7143 & 0.2021 & 0.3234 & 0.5810 & \\
\hline
\end{tabular}

Table 4. Fisher's exact test $p$-value and Chi squared value for female population in case of seven observed traits of hand complex (upper triangle - $\chi 2$ value; lower triangle - Fisher exact $p$ value; ${ }^{*} p<0.05 ;{ }^{* *} p<0.01 ;{ }^{* * *} p<0.001$ )

\begin{tabular}{|l|l|l|l|l|l|l|l|}
\hline & D & Dht & Lf & Ln & Ref & Pht & Hc \\
\hline D & & 3.111 & 0.008 & $31.243^{* * *}$ & $8.286^{* *}$ & 0.089 & 1.371 \\
\hline Dht & 0.0802 & & 1.172 & 3.010 & 1.404 & $27.297^{* * *}$ & 0.242 \\
\hline Lf & 0.9397 & 0.2850 & & 1.874 & $20.346^{* * *}$ & 0.006 & 0.003 \\
\hline Ln & $0.0000^{* * *}$ & 0.0902 & 0.1759 & & 0.088 & 0.247 & 0.092 \\
\hline Ref & $0.0045^{* *}$ & 0.2516 & $0.0000^{* * *}$ & 0.8029 & & 1.607 & $4.923^{*}$ \\
\hline Pht & 0.7905 & $0.0000^{* * *}$ & 0.9558 & 0.6459 & 0.2150 & & 0.718 \\
\hline Hc & 0.2468 & 0.6493 & 0.9699 & 0.7881 & $0.0290^{*}$ & 0.3981 & \\
\hline
\end{tabular}



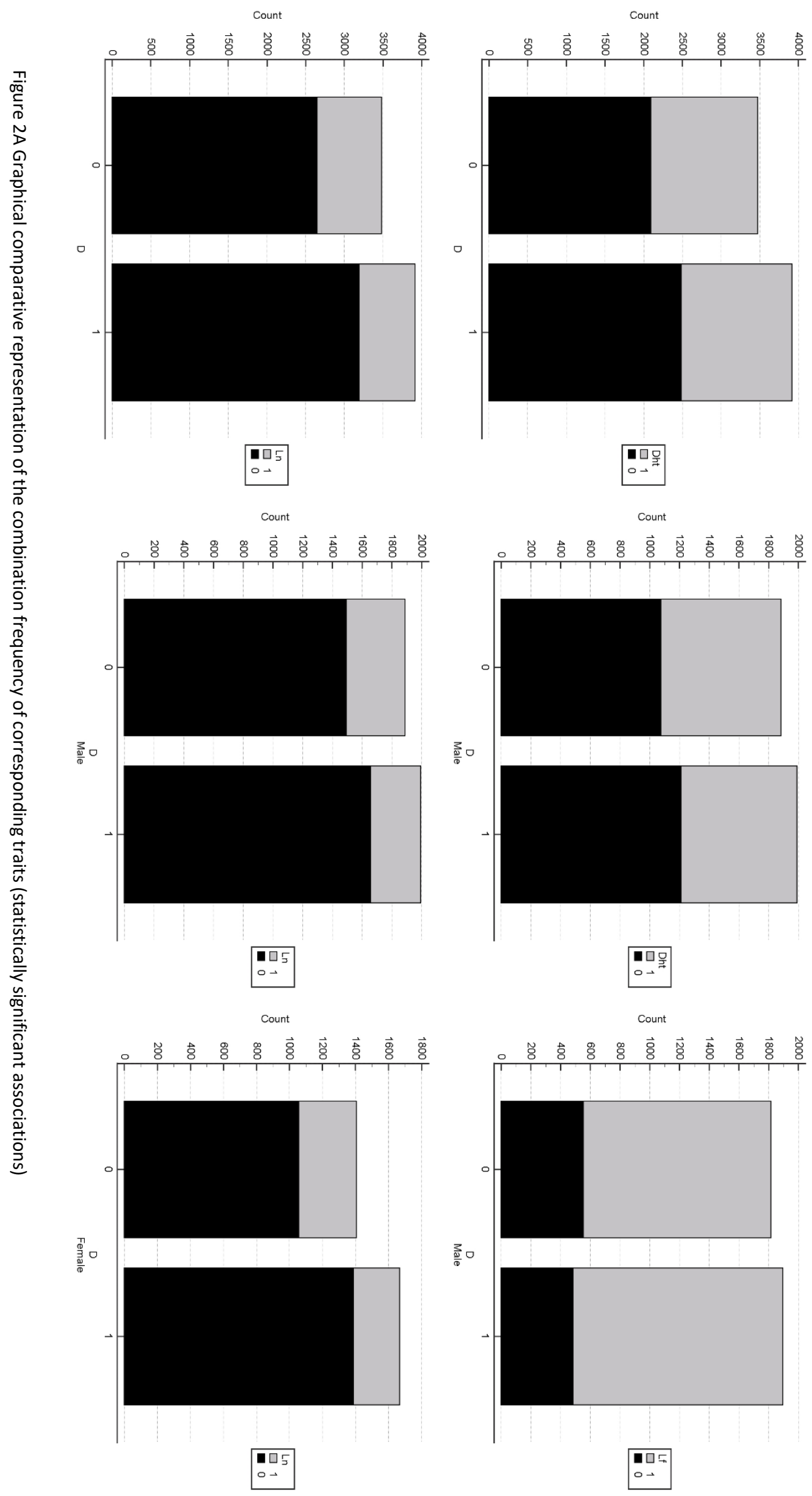

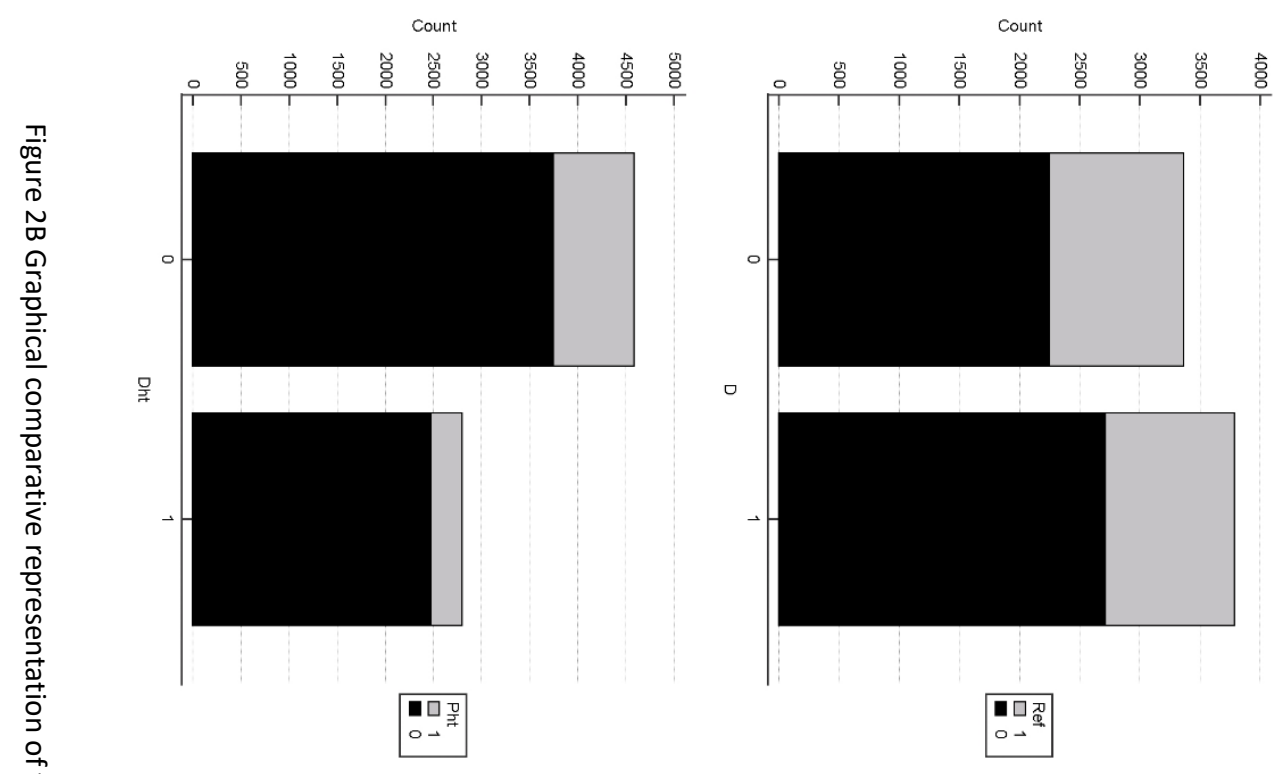

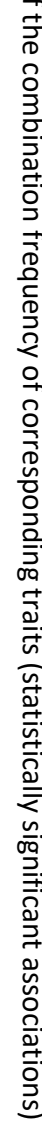
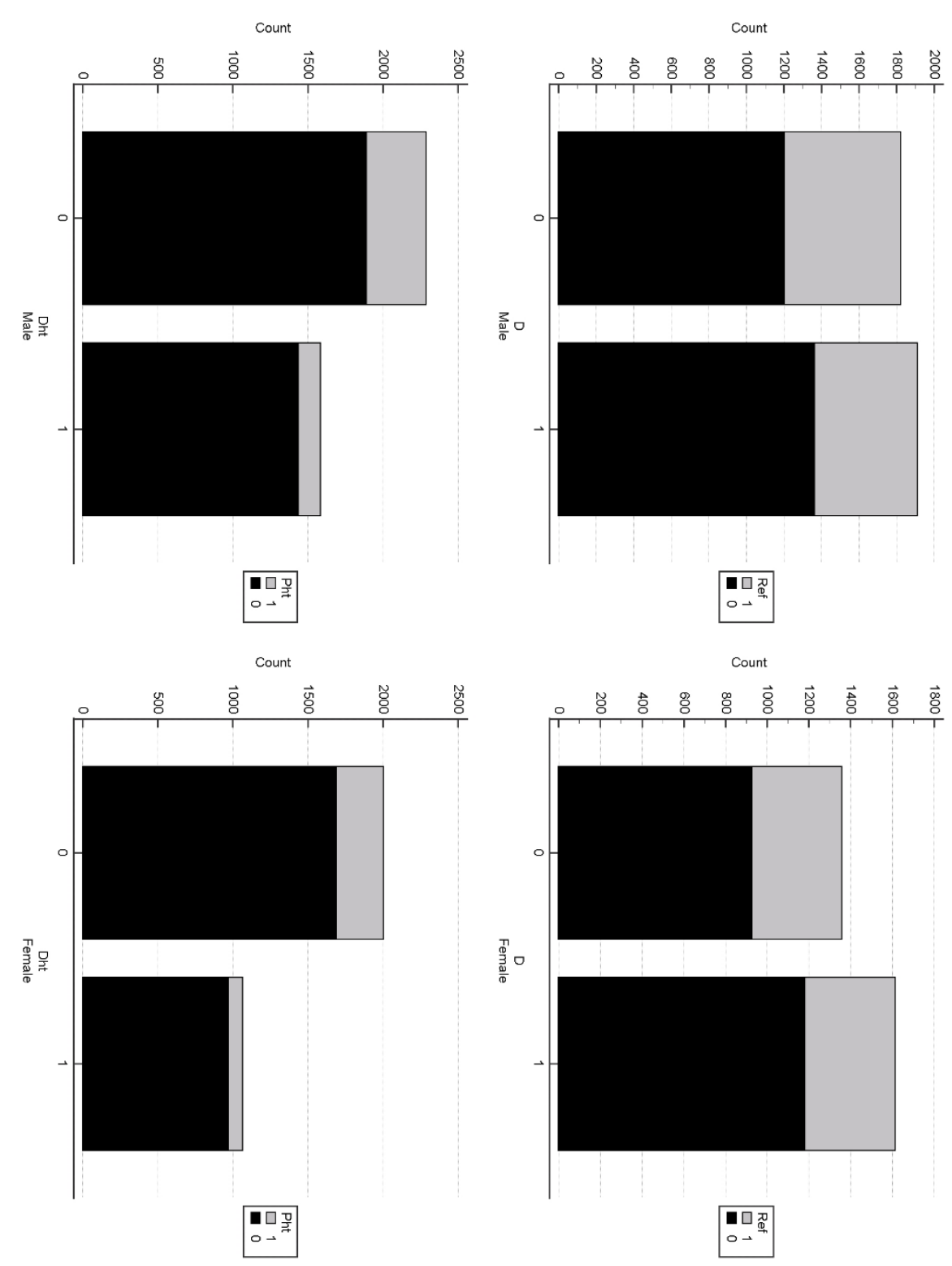


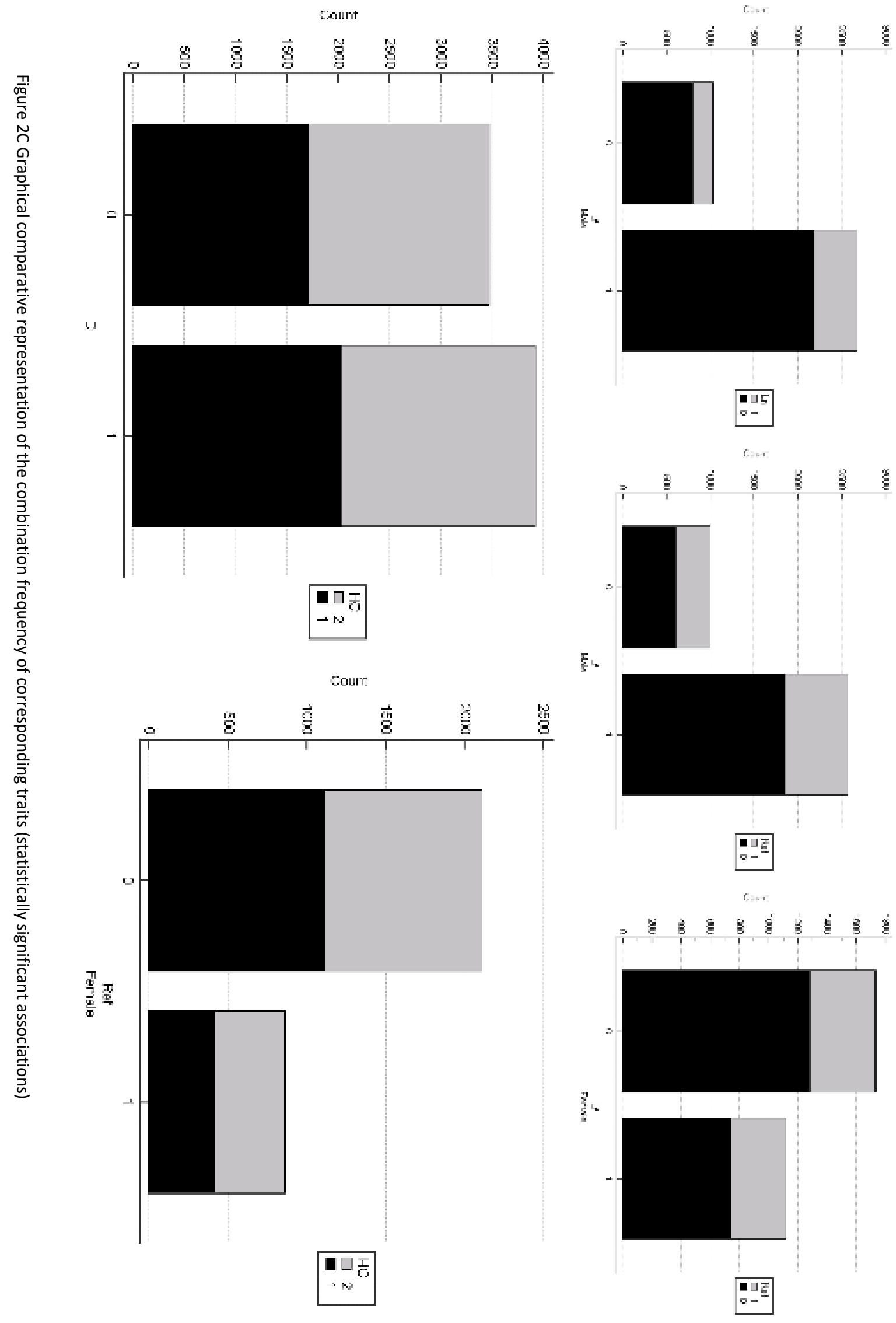


Regarding association between $\mathrm{D}$ and $\mathrm{Dht}$, highest significance was observed in total sample $(x 2=7.976 ; p=$ 0.0047 , Fisher's exact test $p=0.004968586)$. Statistical significance was also observed in group $M(\chi 2=5.596$, $p=0.0180$, Fisher's exact test $p=0.018645058)$. However, regarding $\mathrm{F}$ group statistical significance was not observed $(\chi 2=3.111, p=0.0778$, Fisher's exact test $\mathrm{p}=0.080236612)$. In total sample, the largest proportion of individuals (2489) had hypoextensibility of distal joint of thumb (Hitchhiker's thumb) and presence of midphalangeal hair, and smallest proportion (1378) had hyperextensibility of distal joint of thumb (Hitchhiker's thumb) and absence of midphalangeal hair. In male group, the largest proportion of individuals (1212) had hypoextensibility of distal joint of thumb (Hitchhiker's thumb) and presence of midphalangeal hair, and smallest proportion (779) had hyperextensibility of distal joint of thumb (Hitchhiker's thumb) and presence of midphalangeal hair. In case of association between $D$ and Lf, statistical significance was observed only in group $M(x 2=11.485, p=0.0007$, Fisher's exact test $p=$ $0.000760890)$. In group $F(\chi 2=0.008, p=0.9296$, Fisher's exact test $p=0.939756783$ ) statistical significance was not observed. In male group, the largest proportion of individuals (1412) had short index finger and presence of midphalangeal hair, and smallest proportion (484) had long index finger and presence of midphalangeal hair. In cases D and Ln, D and Ref and Dht and Pht statistical significance was observed in all 3 groups T, F, $M$. Also highest significance in total was observed in these cases, especially Dht and Pht. In group $\mathrm{T}$ values are as follows $(\chi 2=58.979, p=<0.0001$, Fisher's exact test $p=<0.000000001)$, group $F(x 2=27.297, p=<0.0001$, Fisher's exact test $p=0.000000100)$ and group $M(\chi 2=$ 50.504, $p=<0.0001$, Fisher's exact test $p=$ $<0.000000001)$. As for Dht and Pht case, in total group, the largest proportion of individuals (3746) had hypoextensibility of proximal joint of thumb and hypoextensibility of distal joint of thumb (Hitchhiker's thumb), and smallest proportion (326) had hyperextensibility of proximal joint of thumb and hyperextensibility of distal joint of thumb (Hitchhiker's thumb). In female group, the largest proportion of individuals (1690) had hypoextensibility of proximal joint of thumb and hypoextensibility of distal joint of thumb (Hitchhiker's thumb), and smallest proportion
(95) had hyperextensibility of proximal joint of thumb and hyperextensibility of distal joint of thumb (Hitchhiker's thumb). Also in male group, the largest proportion of individuals (1891) had hypoextensibility of proximal joint of thumb and hypoextensibility of distal joint of thumb (Hitchhiker's thumb), and smallest proportion (148) had hyperextensibility of proximal joint of thumb and hyperextensibility of distal joint of thumb (Hitchhiker's thumb). In case of $D$ and $L n$ values are: group T ( $\chi 2=31.343, p=<0.0001$, Fisher's exact test $p=0.000000025)$, group $F(\chi 2=31.243, p=<0.0001$, Fisher's exact test $p=0.000000030)$ and group $M(\chi 2$ $=10.208, p=0.0014$, Fisher's exact test $p=0.001529606$ ). In this example it was obvious to conclude that the lowest statistical significance was observed in group $\mathrm{M}$. In total group, the largest proportion of individuals (3195) had non-flat nail shape and presence of midphalangeal hair, and smallest proportion (728) had flat nail shape and presence of midphalangeal hair. In female group, the largest proportion of individuals (1390) had non-flat nail shape and presence of midphalangeal hair, and smallest proportion (278) had flat nail shape and presence of midphalangeal hair. Also in male group, the largest proportion of individuals (1659) had non-flat nail shape and presence of midphalangeal hair, and smallest proportion (335) had flat nail shape and presence of midphalangeal hair. The last example in which statistical significance was registered in all three groups is $D$ and Ref. In group $T$ values were $(\chi 2=19.858, p=<0.0001$, Fisher's exact test $p=0.000008737)$, group $F(\chi 2=8.286, p=0.0040$, Fisher's exact test $p=0.004519130)$ and group $M(\chi 2=11.994$, $p=0.0005$, Fisher's exact test $p=0.000545274)$. Highest statistical significance was observed in group $T$, followed by group $M$ and group $F$. In total group, the largest proportion of individuals (2717) had abnormally crooked fifth finger and presence of midphalangeal hair, and smallest proportion (1073) had normal fifth finger and presence of midphalangeal hair. On the other side, in female group, the largest proportion of individuals (1181) also had abnormally crooked fifth finger and presence of midphalangeal hair, however, smallest proportion (430) had normal fifth finger and absence of midphalangeal hair. In male group, the largest proportion of individuals (1364) had abnormally crooked fifth finger and presence of midphalangeal 
hair, while smallest proportion (550) had normal fifth finger and presence of midphalangeal hair. Regarding association between Lf and Ln statistical significance was observed only in group $M(\chi 2=7.184, p=0.0074$, Fisher's exact test $p=0.008111623)$, while statistical significance was not observed in group $F(\chi 2=1.874$, $p=0.1710$, Fisher's exact test $p=0.175861855)$. In male group, the largest proportion of individuals (2191) had non-flat nail shape and short index finger, while the smallest proportion (228) had flat nail shape and long index finger. Association of Lf and Ref traits showed statistical significance in groups $F(\chi 2=20.346$, $p=<0.0001$, Fisher's exact test $p=0.000007402$ ) and $M$ $(x 2=41.238, \quad p=<0.0001, \quad$ Fisher's exact test $p=<0.000000001)$. Therefore, it is logical to conclude that highest statistical significance in this case was registered in group $M$. In female group, the largest proportion of individuals (1285) had abnormally crooked fifth finger and short index finger, and the smallest proportion (378) had normal fifth finger and long index finger. In male group the situation was similar, the largest proportion of individuals (1855) had abnormally crooked fifth finger and short index finger, and the smallest proportion (391) had normal fifth finger and long index finger Regarding association between $D$ and $\mathrm{Hc}$ statistical significance was registered only in group $\mathrm{T}(\chi 2=4.692, \mathrm{p}=0.0303$, Fisher's exact test $p=0.032093967)$. In groups $F(x 2=1.371, p=0.2416$, Fisher's exact test $p=0.246670517)$ and $M(x 2=2.604$, $p=0.1066$, Fisher's exact test $p=0.108240593)$ statistical significance was not observed. In total group, the largest proportion of individuals (2030) had right side hand clasping and presence of midphalangeal hair, while the smallest proportion of individuals (1711) had also right side hand clasping and absence of midphalangeal hair. In case of association between Ref and $\mathrm{Hc}$ statistical significance was observed in group $\mathrm{F}$ only $(\chi 2=4.923, p=0.0265$, Fisher's exact test $\mathrm{p}=0.028970327)$. Statistical significance was not registered in groups $T(\chi 2=3.599, p=0.0578$, Fisher's exact test $p=0.060997732)$ and $M(\chi 2=0.991, p=$ 0.3196, Fisher's exact test $p=0.323410665)$. In female group, the largest proportion of individuals (1108) had right side hand clasping and abnormally crooked fifth finger, while the smallest proportion (414) had also right side hand clasping and normal fifth finger.
Statistical significant association was not registered between following traits: Midphalangeal hairExtensibility of proximal joint of thumb, Hitchhiker's thumb-Digital index, Hitchhiker's thumb-Crooked fifth finger, Digital index-Extensibility of proximal joint of thumb, Nail shape-Crooked fifth finger, Crooked fifth finger-Extensibility of proximal joint of thumb, Extensibility of proximal joint of thumb-Hand clasping, Nail shape-Hand clasping, Digital index-Hand clasping, Hitchhiker's thumb-Hand clasping, Hitchhiker's thumbnail shape and nail shape - extensibility of proximal joint of thumb. Regarding $D$ and Pht following results were obtained which purely suggests lack of statistical significance among all 3 groups: $\mathrm{T}(\chi 2=0.016, p=0.8999$, Fisher's exact test $p=0.923847792) ; F(\chi 2=0.089$, $\mathrm{p}=0.7649$, Fisher's exact test $\mathrm{p}=0.790533135) ; \mathrm{M}(\chi 2$ $=1.224, p=0.2685$, Fisher's exact test $p=0.269928151)$. In case of Dht and Lf statistical significance was not found: $F(\chi 2=1.172, p=0.2790$, Fisher's exact test $p=$ $0.285018113) ; M(\chi 2=1.994, p=0.1580$, Fisher's exact test $p=0.167816247)$. Statistical significance was also not registered in association between Dht and Ref: $T$ $(x 2=0.000, p=0.9884$, Fisher's exact test $p=$ $1.000000000) ; F(x 2=1.404, p=0.2360$, Fisher's exact test $p=0.251564880) ; M(\chi 2=0.047, p=0.8283$, Fisher's exact test $p=0.829697700)$. In case $L f$ and Pht statistical significance was not registered: $F(\chi 2=0.006, p=0.9391$, Fisher's exact test $p=0.955834351) ; M(\chi 2=0.011, p=$ 0.9152 , Fisher's exact test $p=0.916518951)$. Statistical significance was not found in all three groups regarding association between $\operatorname{Ln}$ and Ref: $T(\chi 2=0.006, p=$ 0.9371 , Fisher's exact test $p=0.950060646) ; F(\chi 2=$ $0.088, p=0.7672$, Fisher's exact test $p=0.802901021$ ); $M \quad(\chi 2=0.454, p=0.5004$, Fisher's exact test $p=0.528605720$ ). Case Ref and Pht was also one of the cases where statistical significance was not observed. Group T showed following results $(\chi 2=1.676, p=0.1954$, Fisher's exact test $p=0.207934253)$; group $F$ following results $(\chi 2=1.607, p=0.2049$, Fisher's exact test $p=$ $0.215016014)$ and group $M$ following results $(\chi 2=$ $1.596, p=0.2064$, Fisher's exact test $p=0.225658910)$. Statistical significance between association of Pht and $\mathrm{Hc}$ was not registered in all three groups: $\mathrm{T}(\chi 2=0.002$, $p=0.9610$, Fisher's exact test $p=0.974636342) ; F(\chi 2$ $=0.718, p=0.3969$, Fisher's exact test $p=0.398064529)$; $M \quad(x 2=0.341, p=0.5593$, Fisher's exact test 
$\mathrm{p}=0.581037977)$. In case of $\mathrm{Ln}$ and Hc statistical significance was not observed. Group $T$ showed following results $(\chi 2=1.445, p=0.2294$, Fisher's exact test $\mathrm{p}=0.231078861)$; group $\mathrm{F}$ following results $(x 2=0.092, \quad p=0.7611, \quad$ Fisher's exact test $p=0.788142971)$; group $M$ following results ( $\chi 2=1.699$, $p=0.1924$, Fisher's exact test $p=0.202158623$ ). Statistical significance was also not observed in case of association between $\mathrm{Lf}$ and $\mathrm{Hc}$ in all three groups: $\mathrm{F}(\mathrm{X} 2$ $=0.003, p=0.9556$, Fisher's exact test $p=0.969964492)$; $\mathrm{M} \quad(\chi 2=0.138, p=0.7106$, Fisher's exact test $\mathrm{p}=0.714351184)$. Regarding Dht and $\mathrm{Hc}$ following results were obtained which suggests lack of statistical significance among these traits. Significance was not found in all three groups: $T(\chi 2=0.071, p=0.7902$, Fisher's exact test $p=0.792048907) ; F(x 2=0.242$, $\mathrm{p}=0.6231$, Fisher's exact test $\mathrm{p}=0.649306981) ; \mathrm{M}(\mathrm{X}=$ $0.477, p=0.4898$, Fisher's exact test $p=0.492630053)$. In case of association between Dht and Ln statistical significance was not observed in any group: $\mathrm{T}(\mathrm{X} 2=$ 3.613, $p=0.0573$, Fisher's exact test $p=0.061250992) ; F$ $(x 2=3.010, \quad p=0.0828, \quad$ Fisher's exact test $\mathrm{p}=0.090187515) ; \mathrm{M}(\chi 2=0.742, \mathrm{p}=0.3891$, Fisher's exact test $p=0.402617708)$. In case of $\mathrm{Ln}$ and Pht, statistical significance was not observed in all three groups: $T$ $(x 2=1.997, \quad p=0.1576, \quad$ Fisher's exact test $\mathrm{p}=0.161041198) ; \mathrm{F}(\mathrm{X} 2=0.247, \mathrm{p}=0.6191$, Fisher's exact test $p=0.645890662) ; M(\chi 2=2.185, p=0.1393$, Fisher's exact test $p=0.141195402)$.

There are not many papers in the scientific literature that include estimates of the association of morphological phenotypic traits, especially when it comes to hand. Thus, this paper has an additional value because a potential association of phenotypic traits is studied in a large number of unrelated individuals. The reason why it was decided to observe seven traits of hand is the assumption about the possible association of phenotypic traits since it is the same part of the body. The results of this study indicate the association of certain phenotypic traits of hand, distinguishing three different types of results. The first is that a statistically significant association was observed in both the total population and the gender-differentiated populations. The second type of results is statistically significant association observed only in the total population and the third type only in populations determined by gender. Of all the phenotypes in this study, the digital index and its association (Phelps, 1952) were studied the most. One reason is the different inheritance according to gender where female and male group have different dominant and recessive trait (Table 1). It is indicative that in most associations the largest number of individuals had dominant phenotypes for both traits. Only in one case, there was a situation where individuals had dominant-recessive phenotypes in associated traits. Mainly studies on other traits have been done to assess the differentiation of certain phenotypic characteristics with respect to gender association.

\section{Conclusion}

The assumption about the phenotypic association of hand traits is related to a total of nine combinations of traits. The phenotypic association of hand traits in gender groups ( $M$ and $F$ ) was observed in four combinations. It is obvious that the polygenic combinatorics of the genetic background of these traits indicates the connection of a certain number of genes, since they are polygenic traits. Detailed knowledge about the mechanism of inheritance would supplement the understanding of the genetic relationship of certain genes that form the basis of inheritance.

\section{References}

Berberovic, Lj. (1969). Theoretical frequencies of allelogenes IA, IB and $I^{\circ}$ in the population of Bosnia and Hercegovina. Acta Med. lugosl. 23:62.

Berberovic, Lj. (1978). [in Bosnian] Populaciono-genetička analiza učestalosti alternativnih fenotipova sekrecije $A B H$ antigena $u$ dvanaest uzoraka stanovništva BiH. Glas. Antropol. Druš. Jugosl. 5:47-59.

Berberovic, Lj., Hadziselimovic, R., Maric, C., et al. (1976). [in Bosnian] Populacijska genetika osnovnih krvnih grupa MN sistema u uzorku slučajeva spornog očinstva. First Congress of Yugoslav Geneticists, Dubrovnik, Croatia, Summaries: 14.

Bernstein, M. E. (1949). The middigital hair genes; their inheritance and distribution among the white race. The Journal of heredity, 40(5), 127-131.

Danforth, C.H. (1921). Distribution of hair on the digits in man. American Journal of Physical Anthropology 4: 189-204. 
Dogan, S., Asic, A., Dogan, G., et al. (2016). Y-chromosome haplogroups in the Bosnian-Herzegovinian population based on 23 Y-STR loci. Hum. Biol. 88:201-209.

Dutta, P. (1965). The Inheritance of the Radially Curved Little Finger. Acta genetica et statistica medica, 15, 70-76.

Ecker, A. (1875). Einige bemerkungen über ein schwankenden charakter in der hand des menschen. Arch. Anthrop. Brnschw. 8:6774. [in German]

Gillin, J. (1959). Varietas in modern man. Human evolution. (Korn N, Reece S-H, 1959), Henry Comp., New York.

Glass, B., and Kistler, J. C. (1953). Distal hyper-extensibility of the thumbs. Acta genetica et statistica medica, 4(2-3), 192-206.

Hadziselimovic, R. (1977). [in Bosnian] Genetika sekrecije ABH antigena u stanovništvu Bosne i Hercegovine. God. Biol. Inst. Univ. Sarajevu. 30:29-104.

Hadziselimovic, R. (1981). Genetic distance among local human population in Bosnia and Herzegovina (Yugoslavia). Coll. Antropol. 5:63.

Hadziselimovic, R., and Terzic, R. (1985). [in Bosnian] Populacijska genetika krvnih grupa $A B O$ i Rh sistema u stanovništvu banjalučke bihaćke regije. God. Biol. Instituta Univ. Sarajevu. 38:143-150.

Hefner, R. A. (1929). Inheritance of crooked little fingers (minor streblomicrodactyly). J. Hered. 20: 395-398.

Hersh, A.H., DeMarinis, F., Stecher. R.M. (1953). On the inheritance and development of clinodactyly. American Journal of Human Genetics 5: 257-268.

Kaunic, P., and Grin, E. (1963). [in Bosnian] Krvne grupe stanovništva. Naučno društvo BiH - Posebna izdanja 3:621-625.

Kapur-Pojskic, L., Pojskic,N., Radosavljevic, G., Marjanovic, D., Hadziselimovic, R. (2014). MtDNA variation within local human populations in Bosnia and Herzegovina. Genetika., 46(1): 209-218.

Kovacevic, L., Tambets, K., Ilumäe, AM., Kushniarevich, A., Yunusbayev, B., Solnik, A., Bego, T., Primorac, D., Skaro, V., Leskovac, A., Jakovski, Z., Drobnic, K., Tolk, H.V., Kovacevic, S., Rudan, P., Metspalu, E., Marjanovic, D. (2014). Standing at the Gateway to Europe - The 226 Genetic Structure of Western Balkan Populations Based on Autosomal and Haploid Markers. PLoS One., 9(8): 105090.

Kovacevic, L., Fatur-Ceric, V., Hadzic, N., Cakar, J., Primorac, D., Marjanovic, D. (2013). Haplotype data for 23 Y-chromosome markers in a reference sample from Bosnia and Herzegovina. Cro Med J., 54(3): 286-290.

Lai, L. Y., \& Walsh, R. J. (1965). The patterns of hand clasping in different ethnic groups. Human biology, 37(3), 312-319.
Lasic, L., Cakar J., Radosavljevic, G., Kalamujic, B., Naris, P. (2016). Historical Overview of the Human Population-Genetic Studies in Bosnia and Herzegovina: Small country, Great Diversity. Coll Antropol., 40(2): 145-149.

Lasic, L., Lojo-Kadric, N., Silajdzic, E., et al. (2013). Moleculargenetic variance of RH blood group system within human population of Bosnia and Herzegovina. Bosn. J. Basic Med. Sci. 13:10-13.

Lasic, L., Kalajdzic, A., Kalamujic Stroil, B., Pojskic, L., Hanjalic, J., Usanovic, L., Pojskic, N. (2020) Molecular Variation of Rh, MN, Duffy, Kidd, Kell, and Lutheran Blood Groups in the Human Population of Bosnia and Herzegovina. Human Biology, 92(2): 81-92.

Lutz, F.E. (1908). The inheritance of the manner of clasping the hands. American Naturalist 42.495: 195-196.

Marjanovic, D., Bakal, N., Pojskic, N., et al. (2006). Allele frequencies for 15 short tandem repeat loci in a representative sample of Bosnians and Herzegovinians. Forensic Sci. Int. 156:79-81.

Marjanovic, D., Fornarino, S., Montagna, S., et al. (2005). The peopling of modern Bosnia-Herzegovina: Y-chromosome haplogroups in the three main ethnic groups. Ann. Hum. Genet. 69:757-763.

Marjanovic, D., Kapur, L., Pojskic, N., Hadziselimovic, R. (2005a). DNA diversity in the studies of genetic distance among isolated human popuation in Bosnia. Hum Evol., 20(2-3): 157-166.

Marjanovic, D., Pojskic, N., Kapur, L., Haveric, S., Durmic-Pasic, A., Bajrovic, K., Hadziselimovic, R. (2008). Overview of human population-genetic studies in Bosnia and Herzegovina during the last three centuries: history and prospective. Collegium Anthropologicum 32: 3 pp 981-987.

Munir, S., Sadeeqa, A., Nergis, B., Tariq, N., Sajjad, N. (2015). Assessment of Morphogenetic Inherited Traits; Earlobe Attachment, Bent Little Finger and Hitchhiker's Thumb in Quetta, Pakistan. World Journal of Zoology 10 (4): 252-255.

Nesic, M., Cicevic, S., Ciric, M., Nesic, V. (2010). Middle phalangeal hair distribution in Serbian high school students. Archives of Biological Sciences, 62 (3), pp. 841-850.

Phelps, V. R. (1952). Relative index finger length as a sex-influenced trait in man. American journal of human genetics, 4(2), 72-89.

Pojskic, N. (2003). [in Bosnian] Kompleksna analiza različitih modela proučavanja genetičke distance i njenih mogućih faktora $u$ stanovništvu BiH: magistarski rad.

Pojskic, N., Silajdzic, E., Kalamujic, B., et al. (2013). Polymorphic Alu insertions in human populations of Bosnia and Herzegovina. Ann. Hum. Biol. 40:181-185.

Whitney, D. D. (1942). Family Treasures. Jaques Cattell Press. 